\title{
Better Procurement by Comparing the Behavior of Electronic and Non-Electronic Procurement
}

\author{
Galih Wibowo \\ Regional Secretary of Government of Central Java Province \\ Jalan Pahlawan Nomor 9 Semarang, Central Java Indonesia \\ Tel: 62-24-831-1174Ｅ-mail: galiih.wi@gmail.com
}

Received: June 13, 2016 Accepted: June 17, $2016 \quad$ Published: November 28, 2016

doi:10.5296/csbm.v3i2.10368ＵRL: http://dx.doi.org/10.5296/csbm.v3i2.10368

\begin{abstract}
Paradigm of administrative change the procedures method of government procurement, particularly the open auction method through a pattern of electronic procurement (e-proc). However, the development of e-proc has not been applied to the direct procurement system to purchase the stuf of governmental or procurement goods. Direct Procurement system adheres to a slightly different mechanism with the concept of an open auction. This difference implies the actor behavior in both methods is different too. Studies comparing the behavior of the both actors / organizer on the electronic procurement (public tender) and non-electronic (direct procurement) was conducted to determine the level of performance of government procurement. The factors and impact each of the procurement methods have been studied for understanding advantages and disadvantages of each method, so that it can formulate better procurement models.
\end{abstract}

Keywords: Electronic Procurement, Non-Electronic Methods of Procurement, Procurement Organizer Behavior 


\section{Indonesian Procurement}

Technological issues become very dominant today, included in some of the rules of science and life. In the government sector, the public administration paradigm has adopted information technology/IT, which is better known as electronic government (e-gov) (Helmut, 2005). Dowding also mentioned that the current IT has become a basic necessity for any company, especially in running all aspects of the organization's activities (Dowding, 1995). The role of IT in various aspects of business activities can be understood because as a technology that focuses on setting up information systems with the use of computers, IT can meet the information needs of the business world very quickly, timely, relevantly and accurate (Wilkinson \& Cerullo, 2000).

Indonesia is a developing country, e-government also scheduled as part of bureaucratic reform in there. E-government is applied not just about systems and mechanisms for offices, but also public services, public information, as well as the procurement of government goods and services or public procurement.

The principle of public procurement is the process of acquisitions made by the government and public institutions to obtain goods, infrastructure construction, and services in a transparent, effective, and efficient in accordance with the needs and desires of its users (Edquist et al., 2000). The process of government procurement of goods and services continue to be addressed in order to have a working principle that is efficient, effective, transparent, open, competitive, fair / non discriminatory and accountable. Completion the rules are not only intended to encourage the acceleration of government spending and procurement, but also to suppress the irregularities that occurred as a result of the procurement of government goods and services are higher. The Corruption Eradiction Commission of Indonesia (Komisi Pemberantasan Korupsi) said that of all the cases of corruption handled in Indonesia are handled, corruption is mostly high due to bribery and procurement of goods and services.

One of the efforts to build a good procurement is the implementation of an electronic system called e-procurement. Electronic procurement is not only to suppress the irregularities, but also to minimize face-to-face activities between procurement commitee with prospective providers, paperless activities, and easy to access making it more effective and efficient.

This was in line with Iqbaria, which calls that the individual and collective acceptance of the use of IT can be explained by variations in the use of a system, because it is believed the use of an IT-based system that can develop individual performance or the performance of the organization (Iqbaria, 1994). Implementation of E-government must be implemented to support the governance and administration (United Nations, 2002).

In accordance with Indonesia Presidential Decree Number 54 of 2010 and its amendments, the procurement of goods through electronic system divided into several methods, namely public auction, simple auction, direct appointment, direct procurement, contests and competition. However, basically the procurement is using the principles of public auction. Although the development of the electronic system has been adopted in the procurement 
process, but still there is a method that has not been accommodated in the electronic system, the direct procurement.

In the procurement of goods, direct procurement is a procurement system manual for a maximum nominal value of up to 200 million rupiahs, has a small risk and is intended for small businesses. Electronic systems in procurement as developed procurement services not provide direct procurement method, which is a new form of e-purchasing, with still very limited goods in the e-catalog listed. It was for some areas this method can't be used, because the capacity of the e-catalog still limited to goods. Because of this, direct procurement manually to be more done in government agencies.

Among public auction with an electronic system with non-electronic of direct procurement there is a difference not only in systems that are used. The most difference is related to the actors, the mechanism of the process, and the implementation of the procurement timetable.

At the public auction procurement via e-procurement, the actor who runs the auction process is the procurement committee / working group in a procurement services instutision, which consists of at least 3 (three) people. Meanwhile, the contract document is by the signed Committing Officer or Project Leader (in Indonesia Presiden Decree calls Pejabat Pembuat Komitmen/PPK). Committing Officer as the owner of the work conveying mandate accompanied by supporting documents to the procurement commitee to do the public auction procurement. After receiving the mandate, the procurement commitee has the authority to conduct an auction process independently. Mechanism in electronic procurement processes for public auction procurement using IT-based concept.

While in the non-electronic of direct procurement, use the concept of manually performed by an official procurement. Schedule at public auction electronic procurement system has been determined and loaded into electronic form so that the binding and difficult to change, while the non-electronic procurement schedule can be as shorter and adjust usage.

This difference causes the performance of the implementation of the two methods also differ, one due to different behavior. To determine the level of performance of the procurement of government goods and services, it is necessary to study the behavior of both the process of the procurement, namely public auction using e-proc and non-electronic direct procurement. The aim of research to formulate better procurement concept is based on the behavior and impact.

\section{Literature Review}

As an implementation of the policy, of course, e-procurement needs to be evaluated. Bingham, Felbinger, Howlet, \& Ramesh (Nugroho, 2011, pp. 676-677) classify evaluations into three, namely: a) Administrative evaluation, with regard to the evaluation of the administrative side-budget, efficiency, cost-of processes in government policies with respect to, b) Judicial evaluation, are evaluation with regard to the issue of the legal validity of a policy implemented, including possible violations of the constitution, the legal system, ethics, rules of state administration, to human rights, c) Political evaluation, which assesses the extent to which acceptance of a political constituency for public policy that is implemented. 
Administrative evaluation is perfect for viewing the performance of an organization process.

Administrative evaluation consists of: 1) effort evaluation, judging from the input side programs developed by policy, 2) performance evaluation, which assesses the output (output) of a program developed by the policy, 3) adequacy of performance evaluation or effectiveness evaluations, which assess whether program is run as a predefined, 4) efficiency evaluation, which assesses the cost of the program and provide an assessment of the cost-effectiveness, 5) process evaluations, which assess the methods used by the organization to implement the program. The evaluation process is to understand how the performance of a procurement activities, so the procurement process becomes a focus of study.

Performance services depends on the behavior of the organization that is in it. Robbin said that organizational behavior is a field of study that is invested in the influence of individuals, groups and the structure of the behavior in the organization (Robbin, 2015). According to Bodnar and Hopwood, the user of the system is the human that psychology has a behavior certain inherent, so that aspect in the context of human behaviour as IT user (brain ware) is important as a determinant factor in every person who run the IT (Bodnar \& Hopwood, 1995).

According to Sham consideration of this behavior should receive special attention in the context of the application of IT (Sham, 1999). This opinion is in line with Sung which states that the technical factors, behaviors, situations and personnel IT users need to be considered before IT implementation (Trisnawati, 1998). Henry also suggests that the behavior of the users, and personal development system is needed in the system, and this is related to the understanding and perspective of the system user (Trisnawati, 1998). Furthermore Tompson describes the factors attitude as one of the aspects that influence individual behavior (Tompson et al., 1991). The attitude of a person consists of components of cognitive, affective, and components related to behavior. Attitude toward computer users can be shown with the optimistic attitude that computers are very helpful and useful for troubleshooting or her job (Nur, 2000).

Riyadi explains that one of the internal factors that affect the sources of bureaucratic problems, related to administrative behavioral factors (Riyadi, 2008). One administrative behavior in the bureaucracy is emerging in the division of authority. The division of powers is also included in the determination of providers of goods and services by the offender government procurement. Both in the use of electronic or non-electronic system, the organizer of the procurement (procurement officials / procurement committee) have absolute power and authority in determining the potential winner / providers to be project implementor. This authority is run in accordance with the stages in the method of procurement used.

Therefore, to determine the level of performance of procurement actors, it is necessary to study the behavior of individuals who have the authority procurement organizers choose and assign providers of goods and services. Given the evaluation process is one of the factors to determine the level of performance, then to understand the behavior of the organizers of procurement need to be assessed in each procurement process. At the electronic system and non-electronic has a stage of the procurement process that is different, so as to know the 
behavior of each organizer procurement needs to be studied.

\section{Method}

This study aimed to examine the behavior of individuals who happen to any procurement process either electronic or non-electronic, and seeks to redefine the concept of better taking into account the negative impacts. Qualitative methode descriptive through direct observations made in 2014 to by early 2015. The analytical method used is gender analysis, which used data disaggregated because of the gap between the two things. The use of electronic procurement systems and with non-electronic is a gap that caused the fundamental differences in the concept and mechanism of action of procurement. Through a comparative approach in gender analysis, both the procurement process has to compare, by observing the behavior and impact of each procurement process. Gender analysis using SWOT method put forward so that it can present the advantages and disadvantages of both.

The substance of the research is limited to research the procurement process. This is because in the realm of procurement of non-electronic, more was found in goods procurement process, so as to compare similar things then both the locus of research focused on the procurement of the same. The locus of research in two locations: for e-procurement with open auction supplier in Procurement Services Unit of Central Java Provincial Government. As for non-electronic observe the procurement process, can be done by observing the direct procurement process to choose providers of goods made by the Procurement Official in the Secretary of Central Java Provincial Government. The focus of the study observed the behavior of the procurement committee / working group and behavioral impact on the decision or procurement process.

\section{Research Result \& Analysis}

Although e-proc has to be improved, there is still a procurement mechanism that uses a conventional non-electronic process manually by relying on face to face meetings between actors organizers (officials / procurement committee) with the providers of goods / services. Implementation of the concept of conventional procurement was conducted for the direct purchase method, direct procurement, direct appointment or both goods and services. In the Central Java Provincial Secretary, based on data from the General Procurement Plan 2015, announced a package of 31 contained 25 procurement packages that use direct procurement method. However, the direct procurement of other still not widely publicized.

Based on observation of the procurement process directly non-electronic, general direct procurement carried out by an official procurement with the flow mechanism consists of: 1) Preparation, 2) Announcement or Invitation Offer, 3) Giving Explanation, 4) for submission of bids, 5) Clarification and negotiation, 6) Making a Letter of Results Auction, 7) Determination, 8) Announcement of Winners, 9) Appointment with Provider and 10) Contractual commitment signing.

While the procurement of goods by public auction electronically, on a Procurement Services Unit of Central Java Provincial Government conducted by the procurement commitee 8th and 9th, each of them consisting of three personnel. Based on observation of the procurement 
process electronically, the general flow of the auction mechanism common e-tendering include: 1) Preparation, 2) The announcement, 3) Registration, 4) Giving Explanation, 5) For submission of bids, 6) Evaluation, 7) Making a Letter of Results Auction, 8) Determination, 9) Announcement of Winners, 10) Rebuttal Chance or Claims, 11) Appointment and 12) Contractual commitment signing.

The second glimpse of the procurement process looks the same, only distinguishes announcements and disclaimers. To see the development of behavior in any procurement process, the analysis process is carried out at each stage of the procurement. Based on a review of documents and observation / observation supported by interviews with actors, showed the following results:

Table 1. Comparison of the behavior of the procurement process electronically and non-electronically

\begin{tabular}{|c|c|c|c|}
\hline No. & Stages & $\begin{array}{l}\text { Non-Electronic of Direct } \\
\text { Procurement }\end{array}$ & $\begin{array}{l}\text { Auction Public Electronic } \\
\text { Procurement (e-tendering) }\end{array}$ \\
\hline 1 & Preparation & $\begin{array}{l}\text { During make a documents and } \\
\text { requirements are often determined } \\
\text { based on cues boss, or adjusting the } \\
\text { readiness of the candidate to be } \\
\text { appointed provider, for } \\
\text { procurement officials are } \\
\text { structurally also a subordinate of } \\
\text { the Commiting Officer/Project } \\
\text { Leader. }\end{array}$ & $\begin{array}{l}\text { In document creation and } \\
\text { requirements through the assessment } \\
\text { between the Commiting } \\
\text { Officer/Project Leader and the } \\
\text { procurment committee based on the } \\
\text { essence of procurement and technical } \\
\text { considerations, there is no attempt to } \\
\text { steer the particular provider because } \\
\text { the two sides have equal authority } \\
\text { and not connected by structural lines. }\end{array}$ \\
\hline 2 & $\begin{array}{l}\text { Announcements / } \\
\text { Notifications } \\
\text { Invitation Offer }\end{array}$ & $\begin{array}{l}\text { Announcement is only addressed to } \\
\text { prospective providers designated in } \\
\text { the form of bid invitations, not open } \\
\text { to other communities. }\end{array}$ & $\begin{array}{l}\text { Online announcements can by } \\
\text { witnessed anyone and open to } \\
\text { anyone. }\end{array}$ \\
\hline 3 & Registration & none & $\begin{array}{l}\text { By access the website of procurement } \\
\text { unit. }\end{array}$ \\
\hline 4 & Giving Explanation & The briefing is done face to face. & The briefing is done online \\
\hline 5 & submission of bids & $\begin{array}{l}\text { Submission of bids made after } \\
\text { explanation jobs procced with a } \\
\text { simple document and received } \\
\text { direct procurement officials. }\end{array}$ & $\begin{array}{l}\text { Submission of bids is done by } \\
\text { uploading the document to the } \\
\text { procurement portal and can only be } \\
\text { opened by the procurement commitee } \\
\text { at the time of the evaluation schedule } \\
\text { / opening of bids. }\end{array}$ \\
\hline 6 & $\begin{array}{l}\text { Evaluation } \\
\text { (evaluation of bids, } \\
\text { technical, pricing, }\end{array}$ & $\begin{array}{l}\text { The evaluation and clarification } \\
\text { was done at once, and the results } \\
\text { are still lacking, potential providers }\end{array}$ & $\begin{array}{l}\text { The evaluation was done in stages } \\
\text { until clarification of evidence, and all } \\
\text { of them are shed, for those who do }\end{array}$ \\
\hline
\end{tabular}




\begin{tabular}{|c|c|c|c|}
\hline & $\begin{array}{l}\text { clarification and } \\
\text { verification) and } \\
\text { negotiation }\end{array}$ & $\begin{array}{l}\text { can still equip up to make a deal. } \\
\text { While the negotiations, not only } \\
\text { consider price and technical factors, } \\
\text { but also the commitment of } \\
\text { suppliers to the needs of other } \\
\text { organizations. }\end{array}$ & $\begin{array}{l}\text { not complete immediately fall. While } \\
\text { negotiations only when the input is } \\
\text { less than } 3 \text { offers auction participants, } \\
\text { but very rarely. }\end{array}$ \\
\hline 7 & $\begin{array}{l}\text { Letter of Results } \\
\text { Auction }\end{array}$ & $\begin{array}{l}\text { Created based on the results of the } \\
\text { evaluation and negotiation. }\end{array}$ & $\begin{array}{l}\text { Created based on the results of the } \\
\text { evaluation and negotiation. }\end{array}$ \\
\hline 8 & Determination & $\begin{array}{l}\text { Manufacturer: Defined by the } \\
\text { Procurement in consultation with } \\
\text { the Commiting Officer/Project } \\
\text { Leader. }\end{array}$ & $\begin{array}{l}\text { Providers of goods Defined by } \\
\text { procurement commitee. }\end{array}$ \\
\hline 9 & $\begin{array}{l}\text { Winner } \\
\text { announcement }\end{array}$ & $\begin{array}{l}\text { Has never been found a direct } \\
\text { procurement notices affixed. }\end{array}$ & $\begin{array}{l}\text { Posted on the noticeboard and } \\
\text { published online. }\end{array}$ \\
\hline 10 & $\begin{array}{l}\text { Rebuttal Chance or } \\
\text { Claims }\end{array}$ & $\begin{array}{l}\text { There is no refutation, but open to } \\
\text { the public complaints, but the path } \\
\text { is NO complaints made public, } \\
\text { although contained in the } \\
\text { document. }\end{array}$ & $\begin{array}{l}\text { There are rebuttals could stop and } \\
\text { open procurement process for } \\
\text { complaints. Both disclaimer and } \\
\text { complaints have all been described in } \\
\text { published documents and open lines } \\
\text { of communication. }\end{array}$ \\
\hline 11 & Appointment & $\begin{array}{l}\text { Performed by Commiting } \\
\text { Officer/Project Leader. after } \\
\text { Determination. }\end{array}$ & $\begin{array}{l}\text { Performed by Commiting } \\
\text { Officer/Project Leader. after } \\
\text { Determination. }\end{array}$ \\
\hline 12 & $\begin{array}{l}\text { Contractual } \\
\text { commitment signing }\end{array}$ & $\begin{array}{l}\text { Performed by Commiting } \\
\text { Officer/Project Leader. after } \\
\text { Determination. }\end{array}$ & $\begin{array}{l}\text { Performed by Commiting } \\
\text { Officer/Project Leader. after } \\
\text { Determination. }\end{array}$ \\
\hline 13 & Post-contract & $\begin{array}{l}\text { Post-contract the work, all the } \\
\text { suppliers are still met with } \\
\text { procurement officials, so the } \\
\text { opportunity to do gratuities still } \\
\text { open. }\end{array}$ & $\begin{array}{l}\text { Post-contract work, providers of } \\
\text { goods there is no relationship with } \\
\text { the Working Group, so the possibility } \\
\text { of unlimited gratification. }\end{array}$ \\
\hline 14 & Cost process & $\begin{array}{l}\text { Must be prepare the stationery, } \\
\text { snack for briefing and other. }\end{array}$ & $\begin{array}{l}\text { Paperless, not face to face meeting, } \\
\text { cheaper. }\end{array}$ \\
\hline
\end{tabular}

Behaviors individual procurement organizer is closely associated with the principle of the procurement. Procurement principles are consists of: a) efficient, b) effective, c) transparent, d) openness, e) competition, f) fair/non-discriminatory, and g) accountable. E-procurement principles mentioned above are still very relevant to hold. While the direct procurement of non-electronic, efficient and effective factors most preferred, is intended to faster or procurement process. However, it appears the negative behavior of non-electronic procurement process, namely the opportunity to cheat. Fraudulent behavior is deviant behavior of the organization because it is not in accordance with the principle of the 
procurement specified. Deviant behavior is behavior that violates norms laid down in the organization.

Fraudulent behavior seen in the preparatory process, in which the procurement requirement has been determined and precisely adjust to the prospective supplier will be won. An official procurement only supplementary in a government bureaucracy, and structurally are under boss / top echelon that to be an Commiting officer or project leader also. Bosses can govern an official procurement, because of structural authority so that the selection of providers is not objective. In addition to this, the selection of suppliers is also more due to the closeness between procurement officials with suppliers because of the friendship, or based on the past track record of work. Based on observations of many prospective suppliers who are looking for a project-procurement projects directly with certain sweet promises. From such conditions, it is possible not only administrative requirements that will be set up, but also price manipulation can occur.

Other fraudulent behavior is not the application of the principle of openness, especially in the process of registration and announcement of the winner announcement. In the non-electronic procurement process, announcement of registration is an invitation to offer only one provider to be designated, so that the principles of fair competition and / nondiscriminatory also can't be met, because people do not know the intended procurement information and closed his chances to participate. Similarly, the announcement of the winner, if electronically published openly through the media, but not so with non-electronic procurement. Based on interviews with actors in the procurement of Secretariat of Central Java Government, the announcement of the winner of non-electronic direct procurement was made, but not tacked on the bulletin board, so that people never know about it. Fraudulent behavior also has implications for the gratuities symptomps are very likely arise because the culture of gratitude, especially in the process of determining the terms, appointment of providers and negotiation.

So it can be said that with the electronic system, procurement behavior of the organizers more orderly and optimally adhere to the principle of the procurement. While in the non-electronic system, although its contract value is not too expensive, but the behavior of the organizers of the procurement actually deviates from the norm, with the potential emergence of fraudulent and corrupt behavior.

It can be concluded that the factors that make the procurement offender behavior change are:

a) Individual factors, such as during the announcement of the winner, to which they were not affixed by procurement officials because they think it is less important and less well conditioned public interest to read it.

b) Pressure from leadership, on the pattern of non-electronic procurement, the determination is based on the providers of goods over the appointment by the leadership element. This is because the procurement officers tied up with structural lines of the organization, so that its authority to determine the providers based on an evaluation actually eroded by orders from superiors.

c) Friendship Relationship, althought very rare, and because of the influence of pressure 
bosses, but authorities allow procurement officials to select suppliers based on intuition. Based on the observations, in some procurement this has happened, where procurement officials to give jobs to the procurement of goods providers on the basis of the friendship that has existed over the years. Pressure from superiors boss did not arise because did not have of the competence and interests of the procurement process. For example on the procurement of specialized computer devices, Boss as a project leader have not mastered the computer, so that procurement officers absolute authority to appoint candidates for the provider. This designation is based on relationships that have been established between procurement officials and prospective suppliers. Track record it into consideration, but relationships are also more mainstream consideration.

d) Procurement system, procurement system of non-electronic give wider opportunities for the emergence deviantly, because of the openness and monitoring is limited.

e) The linkage of organizational structure, in the non-electronic direct procurement of goods, the organizer of the procurement that procurement officials in general are on the internal organization of which the boss as the assignor procurement organizations are in the same environment. At the Secretariat of Central Java Province, the procurement official is subordinate staff of the project leader within the same organization, so setting and the Project Leader as a boss commands more attention by the an procurement official. While the electronic procurement, between the project leader as the owner of the work with the procurement commitee no linkage structure. Project Leader are at each institution, while the procurement commitee was in procurement service unit with its own institutional structure, so that the authority of them very independent and hard to influence each other.

Thus conditions shows the relationship between the decision-making factors that cause changes in behavior. In line with the opinion, Joseph Mpeera said "The interactive effects of moral disengagement with work anomie and perceived normative conflict result in the Increase social construction of procurement officers' deviant behavior” (Mpeera, 2010). It means that the relationship between the moral, normative work climate and conflict will affect the increase in behavior that deviates from the procurement officer. Mentioned factors above determines the selection decision-making suppliers in non-electronic procurement process. It is based on the fact that individuals, procurement and project leader as a boss dare to take a chance and risk preference (risk) of what actually deviate from the rules. From this fact, it appears deviant behavior within the organization. This deviant behavior does not arise from mere emotion, but also because of other external factors.

While the impact caused by the emergence of deviant behavior in the procurement of goods, are: a) The procurement process is not running a competitive, fair and open, limiting public participation; b) The decision is not objective, so the quality of the decision is also questionable; c) The existence of violation of norms, not only the rules on procurement of goods and services but also legal norms, related to corruptive behavior; d) the potential losses to the state by the manipulation of the price of goods is higher because the supplier has the burden to pay duty refund, fees and so forth.

On the pattern of procurement, e-procurement application turned out to affect the behavior of 
the organizers of the procurement. With the online system more open and transparent and that the indirect interaction / not face to face, causing the procurement process run better and the potential for small deviations. Therefore, non-electronic direct procurement must be addressed by adopting the advantages of the pattern of electronic procurement.

Further to draft a better future, SWOT analyze be used to map out the good and bad in comparison of the two methods of procurement in question, between the use of e-procurement or non-electronic. The SWOT analysis is presented in table 2.

Table 2. SWOT analysis of procurement of electronic and non-electronic

\begin{tabular}{|c|c|c|c|}
\hline No. & Stages & $\begin{array}{l}\text { Non-Electronic Direct } \\
\text { Procurement }\end{array}$ & $\begin{array}{l}\text { Auction Public Electronic Procurement } \\
\text { (e-tendering) }\end{array}$ \\
\hline 1 & Strength & $\begin{array}{l}\text { Effective and efficient more } \\
\text { advanced, with the freedom to } \\
\text { schedule and instantly determine } \\
\text { the provider of goods / services as } \\
\text { potential implementers. }\end{array}$ & $\begin{array}{l}\text { * Nearly all procurement principles applied } \\
\text { * Open and can be followed by all } \\
\text { communities } \\
\text { * High competitive climate } \\
\text { * The organizers are not in line with the } \\
\text { project leader as a boss, because it is in the } \\
\text { procurement service unit, the independent } \\
\text { institution, so that interventions can be } \\
\text { avoided; } \\
\text { * Potential deviations minimal, there is no } \\
\text { face-to-face and everything is open so the } \\
\text { chances of fraud and corruption narrowed } \\
\text { * Paperless. }\end{array}$ \\
\hline 2 & Weakness & $\begin{array}{l}\text { Procurement officials are at the } \\
\text { same institution structure with the } \\
\text { Project Leader as a Boss, so that it } \\
\text { can intervene } \\
\text { information can't be followed. }\end{array}$ & $\begin{array}{l}\text { Schedule clamped on the application form } \\
\text { system } \\
\text { No procurement officials, because only the } \\
\text { procurement commitee that was formed, so } \\
\text { that when the handle direct procurement } \\
\text { coordination it takes a long time because it } \\
\text { involves many people (at least } 3 \text { person). }\end{array}$ \\
\hline 3 & Oppurtunities & * Faster implementation in time. & $\begin{array}{l}* \text { The development of e-catalog makes it } \\
\text { easy for immediate purchase. }\end{array}$ \\
\hline 4 & Threat & $\begin{array}{l}\text { Potential irregularities is high, } \\
\text { due to lack of implementation of } \\
\text { the principles of open, transparent, } \\
\text { fair, making it appear fraudulent } \\
\text { and corrupt behavior. }\end{array}$ & $\begin{array}{l}\text { Density systems and electronic } \\
\text { interference. }\end{array}$ \\
\hline
\end{tabular}


Based on the SWOT analysis above, the concept of electronic procurement is more favorable, while several advantages as what is shown in the table. However, the concept of provision of non-electronic also has the advantage, albeit a bit but could be a reference for the improvement of the pattern of better procurement. Thus the concept of the best for the future procurement needs to pay attention to the combination of the two methods mentioned above.

\section{Conclusion}

Implementation of the process of government procurement relies heavily on the behavior of the organizers. Such behavior is influenced by: a) the individual actor, b) Pressure leadership/intervention, c) friendship relationship, d) the use of the procurement system, e) linkage structure procurement organization. The impact arising from deviant behavior is extremely detrimental to the climate of business competition, violating legal norms, as well as the potential financial harm state. Implementation of e-procurement can be optimized even though there are still some improvements.

With regard intersection SWOT analysis of procurement auctions on line e-procurement and non-electronic direct procurement, procurement of goods can be arranged concept better future as follows:

1) Implement a procurement system that is not only effective, efficient, but also an opennes, transparent, fair / non-discriminatory, competitive and accountable with the advanced electronic procurement for all kinds of methods of procurement;

2) To avoid intervention and coordination line that takes the offender procurement involves many actors, the need to appoint an official procurement (not commitee) are not on the same structure with the user agencies of goods or project leaders as a boss but being independent institutions such as the Procurement Services Unit. All work can be done through direct spending these officials;

3) Shortcomings that need to be anticipated on schedule confined in a form the pattern of applications as well as the problem of overcrowding systems and electronic interference. Speed processes in non-electronic direct procurement should be adopted. Thus the technical maintenance and improvement of hardware and software systems need to be intensified. Direct procurement of goods electronically can be applied without having to go through an online auction mechanism that takes time, including by creating a system of direct shopping catalog (e-catalog) in collaboration with the company's e-commerce, or create its own system of proper online shopping site exclusively for government purposes.

Looking at the various facts and conclusions arising from the conduct of the procurement, so the need the refinement of methods of procurement is better, hence the need for further discussion of how the government's efforts to formulate the organization, authority and direct procurement system based e-purchasing. Thus not only the procurement can be made more effective and efficient in terms of systems and costs, but also cut all possible deviations. 


\section{Acknowledgement}

This article dedicate from the procurement actor in Central Java Province, Procurement Services Unit in Central Java and Diponegoro University.

\section{References}

Bodnar, H. G., \& Hopwood, S. W. (1995). In A. A. Jusuf \& R. M. Tambunan (eds.), Accounting Information System (6th edition). Jakarta: Salemba Four.

Dowding, K. (1995). Model or Metaphor? Critical Review of the Policy Network Approach. Political Studies XLIII, 136-138. https://doi.org/10.1111/j.1467-9248.1995.tb01705.x

Druke, H. (2005). Local Electronic Government A Comparative Study. London: Routledge Taylor \& Francis Group.

Edquist, C., Hommen, L., \& Tsipouri, L. (Eds.) (2000). Public Procurement Technology and Innovation. Boston, Dordrecht, London: Kluwer Academic Publishers. https://doi.org/10.1007/978-1-4615-4611-5

Higgins, T. R. H. (1991). Personal Computing: Toward a conceptual model of Utilization. Management Information Systems Quarterly, 21(3).

Igbaria, M. (1994). An examination of the factors contributing to microcomputer technology acceptance. Journal of Accounting, Management \& Information Technology, 4, 205-224. https://doi.org/10.1016/0959-8022(94)90023-X

Mpeera, N. J., Sarah, E., \& Mohammed, N. (2010). Moral disengagement and the Social Construction of Procurement Officers' Deviant Behaviours. Journal of Management Policy and Practice vol, 11(4).

Nugroho, R. (2011). Public Policy. Jakarta, PT. Elex Media Komputindo.

Nur, I. (1996). Strategic Information Systems: Impact of Information Technology on organizational and competitive advantage. COMPACT Journal, No. 9 of February. College of Economics, Yogyakarta (YO), Yogyakarta.

Riyadi. (2008). Reforms in Behavioral Perspective Administration. Journal of Administrative Sciences STIA LAN Bandung, 5(1).

Robbins, S. P. (2015). Organization Behaviour (16th edition, Indonesian translation version). Jakarta: Salemba Raya.

Sham, F. B. Z. (1999). The complexity of the impact of information technology for strategy and business continuity. Journal of Accounting and Auditing (JAAI), 3(1), FE. UII Yogyakarta.

Trisnawati, R. (1998). Consideration of behavior and the critical success factors developer of information systems. Journal of business studies, the September issue, Yogyakarta. 


\section{Macrothink}

Case Studies in Business and Management

ISSN 2333-3324

2016, Vol. 3, No. 2

United Nations. (2002). Benchmarking E-Government: A Global Perspective. New York: United Nations.

Wilkinson, C., \& Raval, W. O. W. (2000). Accounting Information Systems: Essential Concepts and Applications, fourth edition. Illinois:Addison Wesley.

\section{Copyright Disclaimer}

Copyright for this article is retained by the author(s), with first publication rights granted to the journal.

This is an open-access article distributed under the terms and conditions of the Creative Commons Attribution license (http://creativecommons.org/licenses/by/3.0/). 